\title{
Possible Mechanisms of Long-Term Trend of June Rainfall over the Korean Peninsula
}

\author{
Hyeran Lee $^{1} \cdot$ Hwan-Jin Song ${ }^{2}$ (D) Byung-Ju Sohn ${ }^{1}$
}

Received: 25 October 2019 / Revised: 22 December 2019 / Accepted: 22 December 2019 / Published online: 8 January 2020

(C) The Author(s) 2020, corrected publication 02/2020

\begin{abstract}
The June rainfall over the Korean peninsula has exhibited a significant decrease in particular after late 1990s. From the Empirical Orthogonal Function (EOF) analyses on the surface temperature, this study found two modes to be closely related to the decrease of rainfall over the peninsula. The first (second) EOF mode is associated with the enhanced surface temperature and anticyclonic circulation over the eastern Lake Baikal to northeastern China (the far East of Russia). The second mode also appears to be related to the cyclonic circulation over the East China Sea and south of Japan islands. These circulation patterns induce southeastward or eastward water vapor transports, and then contribute to the decreased moisture flux convergence and rainfall over Korea. In conclusion, the recent decrease of June rainfall over the Korean peninsula is thought to be, in part, associated with changes in the East Asian Summer Monsoon circulation possibly caused by the local warming trends over the eastern Lake Baikal to Mongolia and far East of Russia.
\end{abstract}

Keywords Korea $\cdot$ June $\cdot$ Rainfall $\cdot$ Drought $\cdot$ East Asia $\cdot$ Monsoon

\section{Introduction}

The East Asian Summer Monsoon (EASM) is an important large-scale circulation system that determines a great deal of the annual precipitation over East Asia. Since the EASM rainfall is a vital source of water for more than one-fifth of the world's population, the monitoring of EASM change has been an important issue in many studies (e.g., Wang 1992; Ha and Lee 2007; Sampe and Xie 2010; Tomita et al. 2011; Xiang and Wang 2013; He et al. 2015; Lin and Wang 2016; Sun et al. 2017). The EASM establishes a long-extended rain band, called as Mei-Yu, Baiu, and Changma fronts in China, Japan, and Korea, respectively. In particular, the Korean peninsula is

The original version of this article was revised due to a retrospective Open Access order.

Responsible Editor: Soon-Il An.

Hwan-Jin Song

hwanjinsong@gmail.com

1 School of Earth and Environmental Sciences, Seoul National University, Seoul, South Korea

2 National Institute of Meteorological Sciences, Korea Meteorological Administration, Jeju, South Korea largely affected by the Changma front with a northwestward propagation of the western North Pacific subtropical high (WNPSH), normally from late June (Ha et al. 2012; Lee et al. 2017). The Changma generally lasts until the end of July. The rainfall during the Changma season over the Korean peninsula is rather dominated by dynamical forcing than the thermal instability (prevalent in August), associated with a large amount of water vapor supply along with the northwestern periphery of the WNPSH (Sohn et al. 2013; Song and Sohn 2015).

In association with Changma, the June rainfall over the Korean peninsula has exhibited a notable decreasing trend during recent four decades (Song and Sohn 2019). It was noted that the northwestward propagation of the WNPSH and southwesterly water vapor flux over the Korean peninsula were much weakened during the recent 20 years, but the mechanism to explain why the WNPSH has been changed was not provided. The recent decreasing trend in the June rainfall over the Korean peninsula may be due in part to interdecadal variation of the EASM system. It was reported that the EASM has been changed drastically around the mid to late 1990s, resulting in the decreased rainfall in eastern China, Korea, and Japan (northern area of EASM region) in contrast to the increased rainfall over the southern area of EASM front band (Kwon et al. 2007; Yim et al. 2014). Ueda et al. (2015) showed that the contrast of sea surface temperature between 
the western and eastern Pacific Ocean around the late-1990s could decrease the rainfall over the northern part of the EASM area while the increase in the rainfall over the southern part of the EASM regions are due to intensified cyclonic circulations around the Philippines.

On the other hand, Northeast China (around Manchuria) has suffered from severe droughts associated with the decadal variation of EASM rainfall (Ding et al. 2008, 2009; Han et al. 2015; Xu et al. 2015; Zhang and Zhou 2015; Piao et al. 2017). Ding et al. (2008) reported that the northward water vapor transport and its convergence by the EASM were much weakened since 1978, leading to reduced moisture supply and rainfall over Northeast China. It was also found that the anticyclonic (high pressure) anomalies over Mongolia to Northeast China was significantly increased after late 1990s, whereas the cyclonic anomalies over southeastern China to the northwestern Pacific (Xu et al. 2015). These decadal circulation patterns caused the southward movement of EASM band, resulting to the decrease of rainfall over Mongolia to Northeast China. The phase shift of Pacific Decadal Oscillation (PDO) has been considered as a main mechanism for the weakening of monsoon circulation and decreasing ainfall in Northeast China (Han et al. 2015; Xu et al. 2015; Zhang and Zhou 2015), because frequent negative PDO after 1990s reduced the landsea thermal contrast by warming in the western North Pacific ocean. Many other causes were suggested such as long-term variation of snow cover in winter and spring over the Tibetan Plateau (Ding et al. 2009), change in the teleconnection pattern with the Indian monsoon (Zhang and Zhou 2015), tropical oceans (Wang and He 2015; Han et al. 2017; Piao et al. 2017; Han et al. 2018), and Artic sea ice cover (Han et al. 2015; Li et al. 2018). Furthermore, Zhu et al. (2012) and Zhang et al. (2019) argued that increased surface heating over Mongolia, in association with global warming, could weaken the occurrence of the low pressure and monsoon rainfall there.

Most of the previous studies (e.g., Kwon et al. 2007; Ding et al. 2008, 2009; Han et al. 2015; Ueda et al. 2015; Xu et al. 2015; Zhang and Zhou 2015; Piao et al. 2017; Zhang et al. 2019) focused on changes in rainfall and associated largescale circulation during the summer months of June-August (or September). However, as discussed in Song and Sohn (2019), the decreasing trend of rainfall around the Korean peninsula was evidently found only in June during the summer months, suggesting the EASM circulation in June may have changed differently from the whole summer. The recent June droughts over Korea and related large-scale circulation changes have not been fully understood yet. In this study, we aim to understand fundamental causes for the recent June droughts over the Korean peninsula in terms of the EASM circulation. For this purpose, we apply various statistical analysis techniques for rainfall and synoptic fields, such as Lepage test, linear regression, Singular Value Decomposition (SVD), and Empirical Orthogonal Function (EOF).

\section{Data}

The June rainfall over the Korean peninsula was obtained from the Korea Meteorological Administration (KMA) Automated Synoptic Observing System (ASOS) data based on rain gauge measurements in manned observatories. In this study, observations at 56 stations excluding four island stations (in Jeju Island and Ulleung-do) over the 39 year period (1979-2017) were considered. In order to examine the tendency of the June rainfall over the East Asia domain $\left(20-60^{\circ} \mathrm{N}\right.$, $\left.100-150^{\circ} \mathrm{E}\right)$, monthly precipitation data from the Global Precipitation Climatology Project (GPCP) version 2.3 in $2.5^{\circ} \times 2.5^{\circ}$ horizontal resolution (Adler et al. 2018) were used. GPCP data provide continuous long-term rainfall record by combining multi-satellite retrievals and rain-gauge observations. In addition, the European Center for Medium-range Weather Forecasts (ECMWF) ERA-interim reanalysis products (Dee et al. 2011) were used to examine possible causes in synoptic fields to the decreasing June rainfall over Korea. In that monthly mean surface (or skin) temperature, geopotential heights at $850 \mathrm{hPa}, 500 \mathrm{hPa}, 350 \mathrm{hPa}$ levels (Z850, Z500, $\mathrm{Z} 300$ ), and vertically-integrated water vapor flux and moisture flux convergence with a $1^{\circ} \times 1^{\circ}$ horizontal resolution were included. Note that vertically-integrated water vapor flux and moisture flux convergence are weighted in lower troposphere because water vapor amount is larger in there.

\section{Results}

Since precipitation over the Korean peninsula has a large interannual variability, the rainfall trend often depends on the analysis period under consideration. Song and Sohn (2019) found that the June rainfall from ASOS 60 stations in South Korea exhibits a gradual decrease of $-27.72 \mathrm{~mm}$ decade $^{-1}$ since 1978. However, focusing on more recent trend analysis after 1998, it had been reported to accelerate to $-70.55 \mathrm{~mm}$ decade $^{-1}$. This study using ASOS 56 stations (excluding four island stations) also exhibits similar results with Song and Sohn (2019), except for statistics (Fig. 1). Here, we analyze the period starting from 1979, to make consistent with other datasets (e.g., GPCP and ERA-Interim data). The decreasing rate of June rainfall for the recent 39 years (1979-2017) is $-18.20 \mathrm{~mm} \mathrm{decade}^{-1}$ with a $90 \%$ confidence level, while the decreasing trend for the recent 20 years (1998-2017) becomes stronger as $-74.90 \mathrm{~mm}$ decade $^{-1}$ with a $99 \%$ confidence level. Yellow squares in Fig. $1 \mathrm{~b}$ indicate drought and flood (or weak and strong rainy) years defined from \pm 1 -standard deviation $(\sigma)$. The years of $1982,1992,1995,2002,2010,2012$, 2014, 2016, and 2017 (1979, 1990, 1996, 1998, 2001, and 2004) are considered as drought (flood) years. Here, the year of 2011 was excluded from flood years, because Typhoon MEARI largely influenced on the rainfall over Korean 
Fig. 1 a Spatial distribution of ASOS 56 stations in South Korea. b Interannual variation of mean June rainfall observed by ASOS 56 stations. Linear trends for different periods (1979-1997, 1998-2017, and 1979-2017) are given with different colors (blue, red, and green). Dotted lines indicate mean \pm 1 -standard deviation (a)

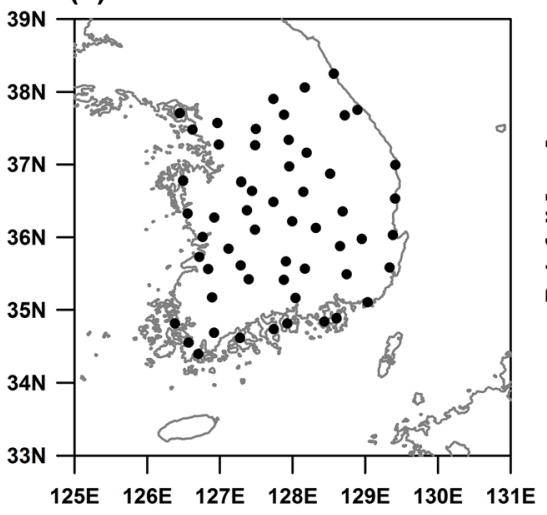

(b)

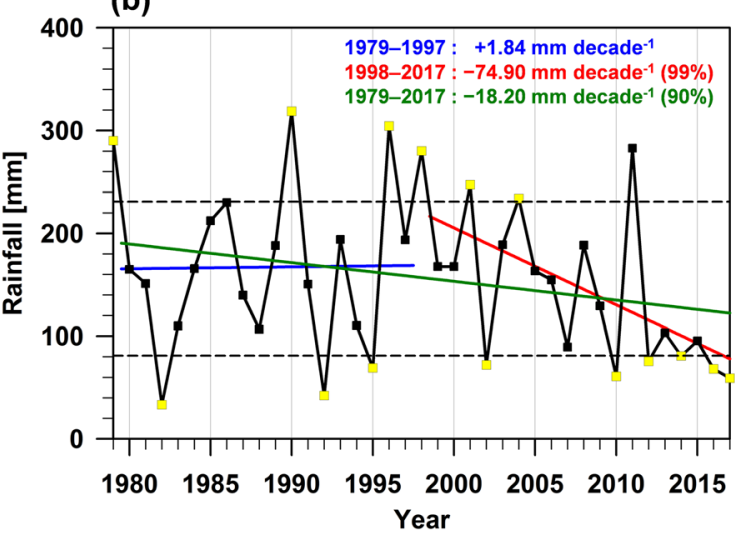

peninsula in June 2011 (refer http://www.typhoon.or.kr for typhoon tracks). Other flood years (i.e., 1979, 1990, 1996, 1998, 2001, and 2004) were not associated with the direct effect of typhoon. Since this study focuses on the EASM large-scale circulation, it is thought to be reasonable to exclude the typhoon effect, which can distort large-scale synoptic fields by one event. It is interesting that the occurrence frequency of drought years after 1998 is twice as frequent compared with those before 1997 and there is no flood year since 2005 (Fig. 1). It suggests that the risk of drought has recently increased over the Korean peninsula.

This study further examines whether there was also a significant change in the GPCP rainfall data over the East Asia domain through a Lepage test, which is a statistical technique for detecting abrupt changes (Yonetani 1992). Here, the test statistics (HK) for the Lepage were calculated every year for \pm 9 -yr periods spanning over the 1987-2008 period. A large HK value suggests a significant change in the target variable. If HK exceeds 4.21 or 5.99 , it is considered to be significant in $90 \%$ or $95 \%$ confidence levels, respectively. A rectangular area of $110-140^{\circ} \mathrm{E}$ and $20-50^{\circ} \mathrm{N}$ was taken for the Lepage test. The distribution for HK value from the Lepage test is shown in Fig. 2. The region of $31-36^{\circ} \mathrm{N}$, where the southern part of the Korean peninsula (as well as Eastern China and

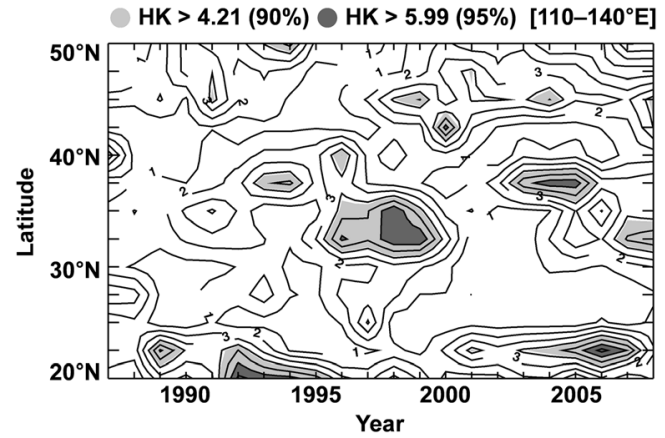

Fig. 2 Time series of zonal $\left(110-140^{\circ} \mathrm{E}\right)$ mean $\mathrm{HK}$ values over from the Lepage test ( \pm 9-yr window) for GPCP June rainfall
Japan) is located, exhibits statistically significant changes at 90\% level in 1996-2000 and 95\% level in 1998-1999. Although not shown in Fig. 2, the year of 1998 was statistically significant at more than the $90 \%$ confidence level even if the analysis window was changed to 7,8 , and 10 years. The results lead to a conclusion that the EASM June rainfall abruptly changed around 1998. The abrupt change in June rainfall around 1998 appears to be associated with the longterm decreasing trend of rainfall over the Korean peninsula shown in Fig. 1. On the other hand, the region of $36-39^{\circ} \mathrm{N}$, where the middle and northern parts of Korea are located, shows abrupt changes in 2003-2006 (with 90\% confidence level) and in 2004-2005 (with 95\% confidence level). The result is thought to be related with frequent drought years and no flood years since 2005 over the Korean peninsula (Fig. 1).

We also examine the spatial distributions of the climatological mean and linear trend of June rainfall in the 1979-2017 period. The climatological mean distribution of June rainfall exhibits a long-extended rain band from southeastern China to the south of Korea and Japan (Fig. 3a), which is well known as EASM front (Wang and LinHo 2002; Ding and Chan 2005). High precipitation region well coincides with the region showing a large water vapor flux and strong moisture flux convergence along the northwestern periphery of the WNPSH (Fig. $3 c)$. However, linear trend of the June rainfall reveals significant changes in pattern, i.e., increasing tendency of rainfall over the East China Sea in contrast to the decreasing tendency over the Korean peninsula (Fig. 3b). These two trends are similar to changes in the May-June rainfall noted in Yim et al. (2014) for the period of 1979-2010, and also consistent with Song and Sohn (2019) results for recent 20 years (19982017) showing the decreased June rainfall over the Korean peninsula.

We speculate that the rainfall trend distribution shown in Fig. $3 \mathrm{~b}$ is thought to be due to the delayed northward movement of EASM front over the Korean peninsula. According to Wang and LinHo (2002) and Wang et al. (2017), the EASM 
Fig. 3 Spatial distributions of climatological June mean of (a) GPCP rainfall $(\mathrm{mm})$ and (c) ERAInterim $850-\mathrm{hPa}$ geopotential height (gpm; contour), and vertically-integrated moisture flux convergence $\left(10^{-3} \mathrm{~g} \mathrm{~m}^{-2} \mathrm{~s}^{-1}\right.$, color) and water vapor flux ( $\mathrm{kg} \mathrm{m}^{-1} \mathrm{~s}^{-1}$, arrows). $\mathbf{b}$ and $\mathbf{d}$ Same as a and c, but for linear trend per decade. In $\mathrm{b}$, the black square denotes a grid point which is significant at the $90 \%$ confidence level. $\mathrm{c}$ and $\mathrm{f}$ Same as a and $\mathrm{d}$, but for difference between drought and flood years in South Korea (a) GPCP rainfall mean

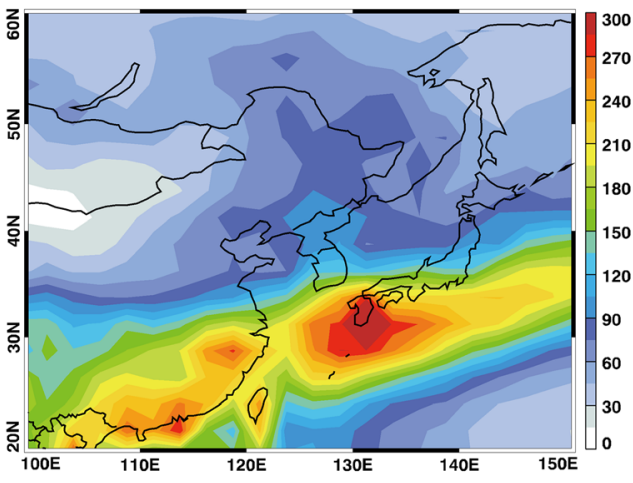

(c) ERA-Interim mean

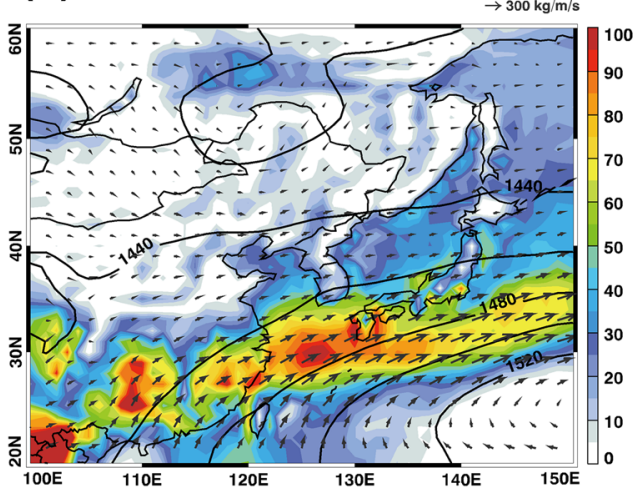

(b) Linear trend

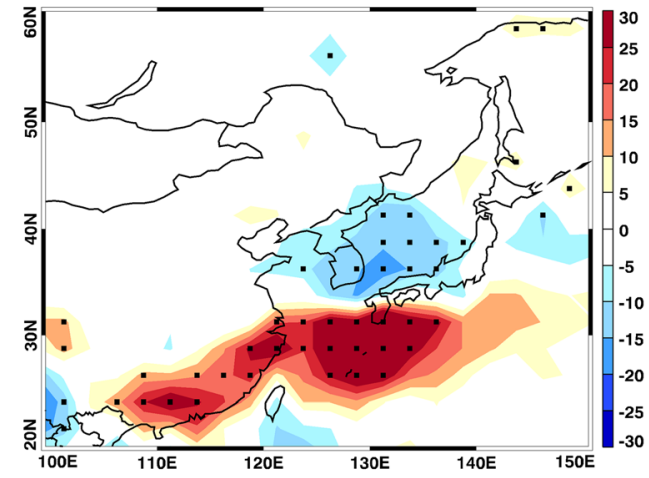

(d) Linear trend

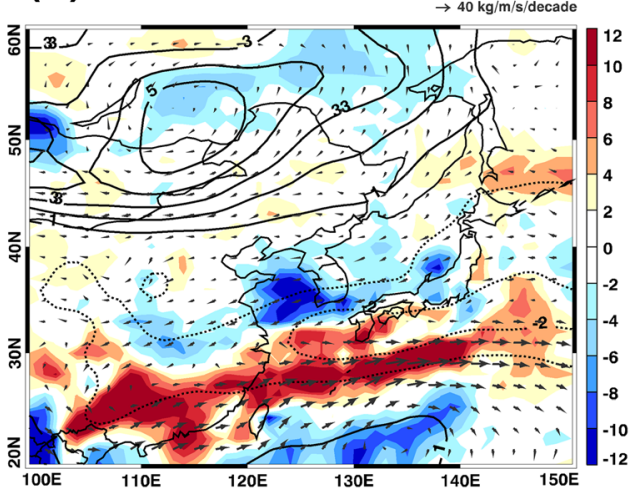

front is normally located in the southeastern China and south of Japan during early June, while it propagates northward toward the Korean peninsula during mid to late June (called as the onset of "Changma' season in Korea). For flood years over the Korean peninsula (i.e., Fig. 4b), the EASM front affects the Korean peninsula from mid-June, whereas the northward propagation of the EASM front is delayed until late June or even July for drought years (i.e., Fig. 4a). The delayed northward movement of EASM front appears to be also consistent with the linear trend of moisture flux convergence, which shows positive moistening trend coincident with the rainfall trend (Fig. 3d). The development of anomalous water vapor convergence and divergence zones appear to be associated with developed anomalous high pressure over the Mongolia and eastern Lake Baikal region whereas decreased pressure tendency south of $40^{\circ} \mathrm{N}$. Such contrast in anomalous pressure systems between two regions tends to hinder the water vapor band (i.e., EASM front) from advancing northward, limiting the water vapor flow in the zonal band extending from southern China to south of Japan through East China Sea (Fig. 3d).

We further examine the difference of rainfall and monsoon circulation between drought and flood years in South Korea (Fig. 4). Figure 4c shows a similar pattern with the linear trend (Fig. 3b), except for the eastward movement for the increased rainfall area from East China Sea to the south of Japan islands. Since the occurrence of drought (flood) years has doubled (halved) since 1999 as shown in Fig. 1, difference between drought and flood years also partly represents the long-term variation of EASM around 1998. Z850 anomaly pattern represents an anticyclonic circulation over the wide area from Lake Baikal to Sea of Okhotsk, but a cyclonic circulation over the south of Japan islands located in the northwestern periphery of the WNPSH, resulting northeasterly water vapor flux and more dry condition over the Korean peninsula (Fig. 4f). The Z850 pattern implies that the WNPSH not expand northward enough due to the continental high pressure anomaly over northeastern Asia, resulting the decreased moisture flux convergence and drought over the Korean peninsula. On the other hand, the rainfall over the south of Japan islands was rather increased. These pressure anomaly patterns are similar with those found in weak and strong Changma years (Ha et al. 2012).

Zhu et al. (2012) and Zhang et al. (2019) reported that the recent increase in high pressure anomalies (i.e., anticyclonic circulation) over northeastern Asia is closely related the strengthened surface heating over that region. The local heating around the Lake Baikal may be partly attributed the global warming (Zhu et al. 2012). This study also investigates the relationship between skin temperature and geopotential heights (850 and $300 \mathrm{hPa}$ levels) fields during the entire 


\section{Drought years}

(a) GPCP rainfall

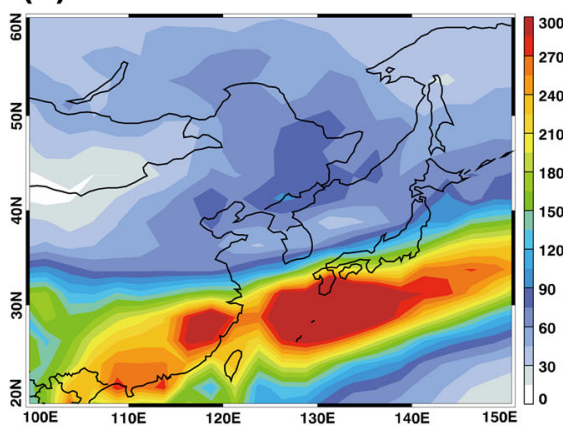

(d) ERA-Interim

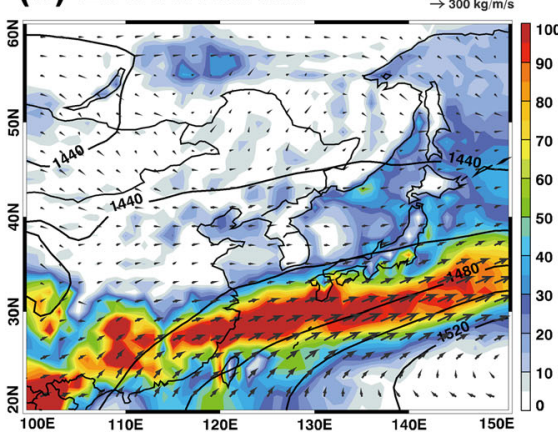

Flood years

(b)

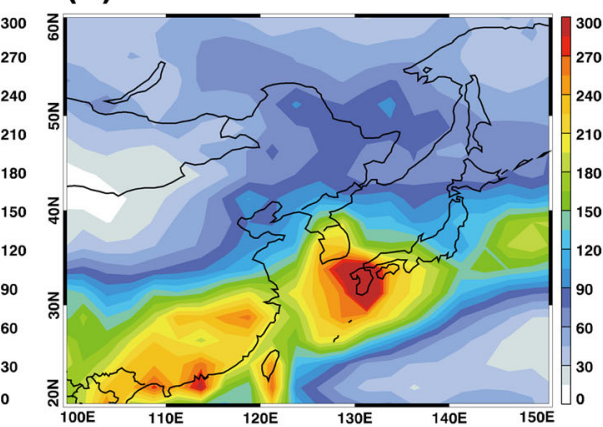

(e)

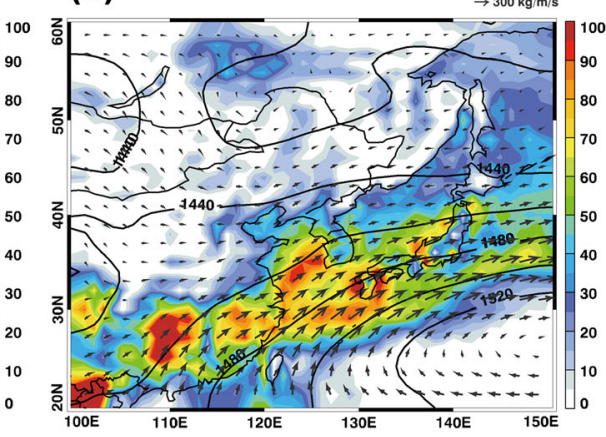

Drought - Flood years

(c)

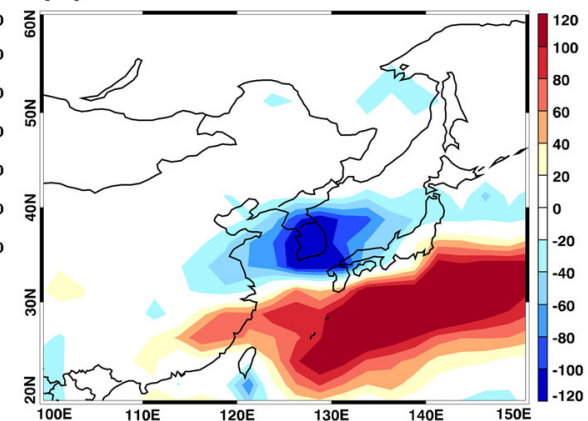

(f)

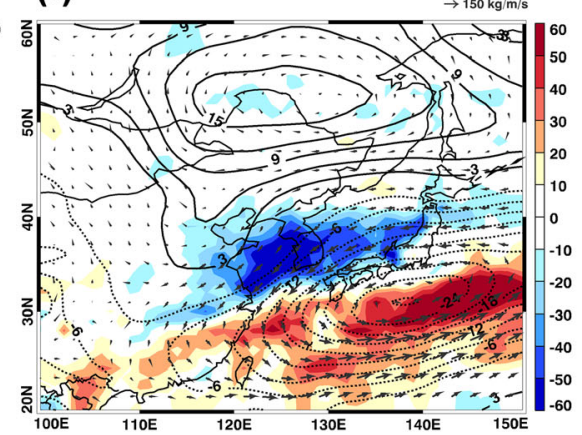

Fig. 4 Spatial distributions of June mean composites between drought and flood years in South Korea for $(\mathbf{a}-\mathbf{b})$ GPCP rainfall $(\mathrm{mm})$ and $(\mathbf{d}-\mathbf{e})$ ERA-Interim 850-hPa geopotential height (gpm; contour), and vertically- integrated moisture flux convergence $\left(10^{-3} \mathrm{~g} \mathrm{~m}^{-2} \mathrm{~s}^{-1}\right.$, color) and water vapor flux ( $\mathrm{kg} \mathrm{m}^{-1} \mathrm{~s}^{-1}$, arrows), and (c and $\left.\mathbf{f}\right)$ their difference analysis period (1979-2017) using the SVD analysis, which is a statistical technique to extract the variability of a combined mode between two variables. The SVD results between skin temperature and Z850 show that two leading modes account for $75.6 \%$ of the total variance (Fig. 5). The first mode explains $60.7 \%$ of the total variation, and two variables (skin temperature and Z850) are temporally closely connected with a correlation coefficient of 0.81 (Fig. 5e). In addition, two variables exhibit both strong positive anomalies in the eastern part of Mongolia and Lake Baikal (Figs. 5a and c). The positive anomalies are extended to the Korea, Japan, and surrounding ocean areas, although the values are small. Decreased skin temperature and Z850 over the Sea of Okhotsk are also interesting, implying the weakening of Okhotsk high. On the other hand, the second mode of SVD analysis (explaining $14.9 \%$ of the total variation) is characterized by a positive anomaly centered on the far East of Russia and a negative anomaly over the East China Sea to the south of Japan islands (Figs. 5b and d). The eastward development of positive anomalies (skin temperature and Z850) toward the far East of Russia and the sign change from positive to negative anomalies over the northwestern Pacific (skin temperature and Z850) are noticeable differences between the first and second SVD modes. The SVD results for skin temperature and Z300 (Fig. 6) show similar patterns with those for skin temperature and Z850 (Fig. 5). In particular, high pressure anomalies the upper troposphere over the eastern Lake Baikal to Mongolia, are closely related to the change of surface temperature. However, the positive anomaly patterns of $\mathrm{Z} 300$ extend to the northwest in the first mode and the northeast in the second mode (Figs. 6c-d), compared with those for Z850 (Figs. 5c-d). In addition, time series of skin temperature are more correlated (higher correlation coefficients) with those of Z300 (Figs. 6e-f) than Z850 (Figs. 5e-f). It is also worthy of note that the years with a positive sign in the time series of expansion coefficients become frequent since the late 1990s in the first modes (Figs. 5e and 6e). The first mode explains the simultaneous relationship in long-term trends between the increased surface temperature and strengthened anticyclonic circulation over the Lake Baikal, eastern part of Mongolia, and Manchuria, as also shown in the linear trend (Fig. 3d). The second mode with high pressure anomaly over the far East of Russia is also thought to have influenced the drought over Korea, along with the that over Lake Baikal, eastern part of Mongolia, and Manchuria. However, the enhanced cyclonic circulation over the south of Japan islands (shown in Fig. 4f) is found only in the second mode (not in the first mode).

We further examine on temporal and spatial changes of skin temperature over East Asia using the EOF analysis, which is a statistical technique to extract representative 
Fig. 5 First two leading SVD modes between skin temperature (left) and 850-hPa geopotential height (Z850; right) fields during June 1979-2017. e and f Time series of expansion coefficients between skin temperature (blue) and $850-\mathrm{hPa}$ geopotential height (red) $1^{\text {st }}$ mode (60.7\%)

(a) Skin Temperature

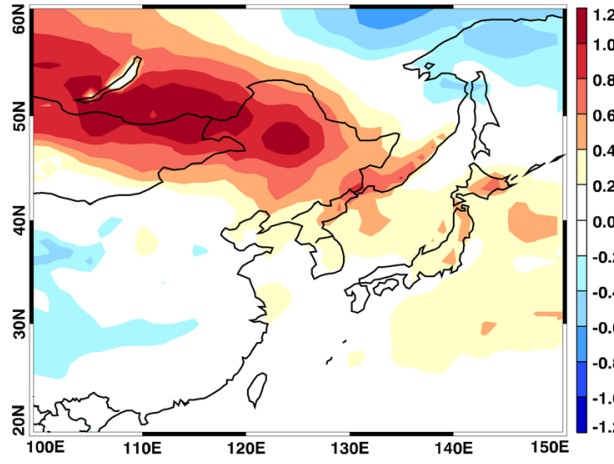

(c) $\mathbf{Z 8 5 0}$

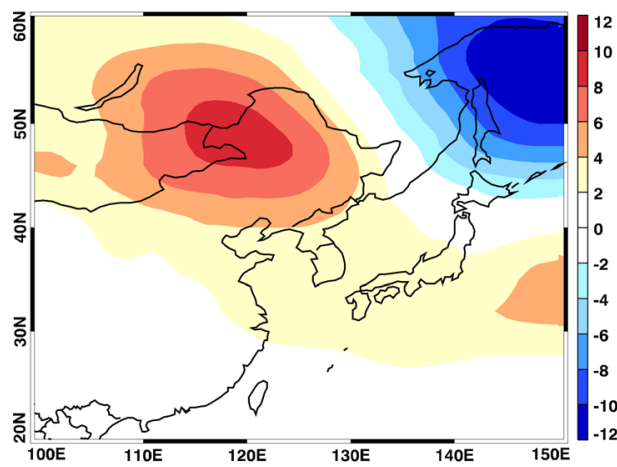

(e) $R=0.81$

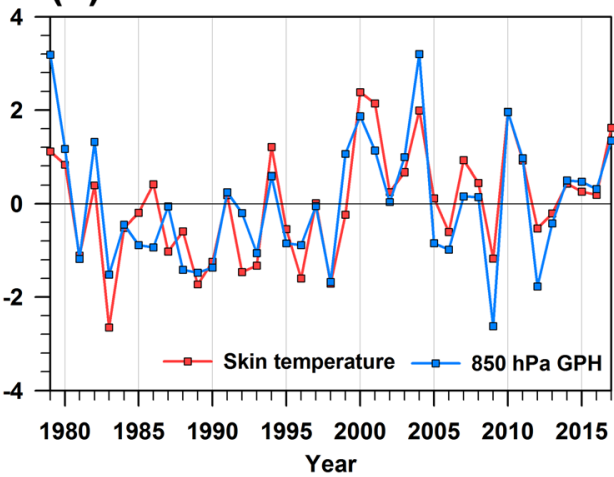

$2^{\text {nd }}$ mode $(14.9 \%)$

(b) Skin Temperature

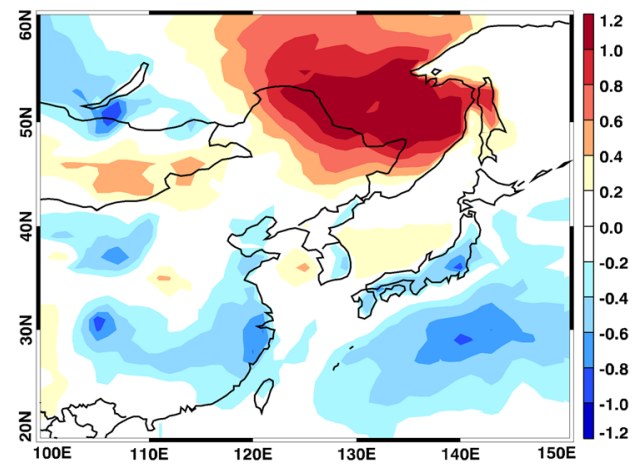

(d) $\mathbf{Z 8 5 0}$

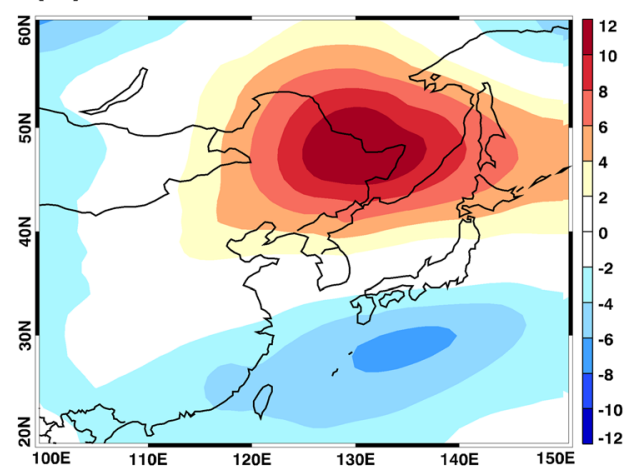

(f) $R=0.73$

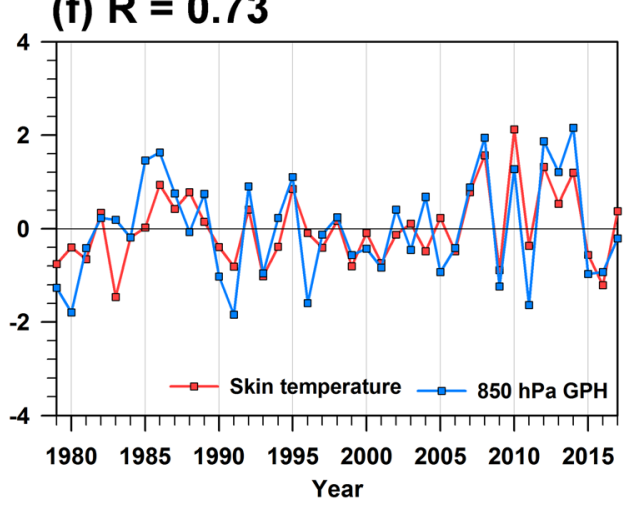

time series and spatial pattern based on orthogonal basis functions. The first two modes from the EOF analysis account for $41.8 \%$ of total variance (Fig. 7). The EOF results represent spatial pattern and temporal variation similar with to those from the SVD analysis, especially for the relationship between skin temperature and Z300 (Fig. 6). This indicates that the coupled mode extracted from the SVD analysis well represents the variability of the skin temperature itself. The first mode of EOF shows a large increase of skin temperature over the eastern regions of Mongolia and Lake Baikal (Fig. 7a), along with the frequent positive values after 2000 in the PC time series (Fig. 7c). This pattern in the first mode is found consistently, even during different analysis periods (Figs. 8a-e). The increasing trend in PC time series for the first mode is significant at a $99 \%$ confidence level. On the other hand, the second EOF mode exhibits an increased temperature over the far East of Russia, but a decreased temperature around the Lake Baikal, eastern Mongolia, Liaodong peninsula, and south of Japan islands (Fig. 7b), in relation to an increasing trend of PC time series which is significant at the $95 \%$ confidence level (Fig. 7d). However, the second EOF modes between two different periods (1979-1997 vs. 1998-2017) exhibit different spatial pattern over the northwestern Pacific, while common warming trends are found in the far East of 
Fig. 6 As in Fig. 4, but for 300$\mathrm{hPa}$ geopotential height $(\mathrm{Z} 300)$ $1^{\text {st }}$ mode $(68.1 \%)$

(a) Skin temperature

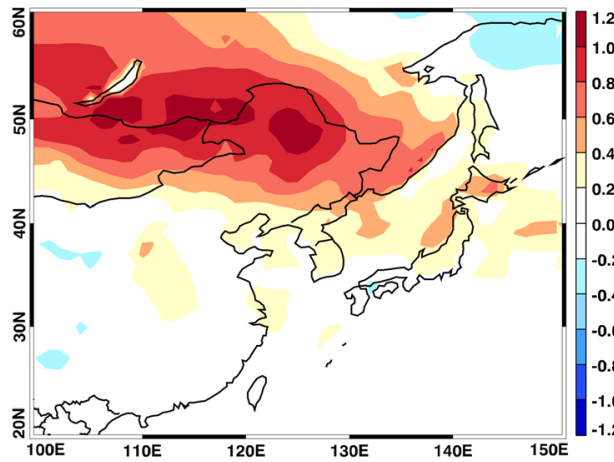

(c) Z300

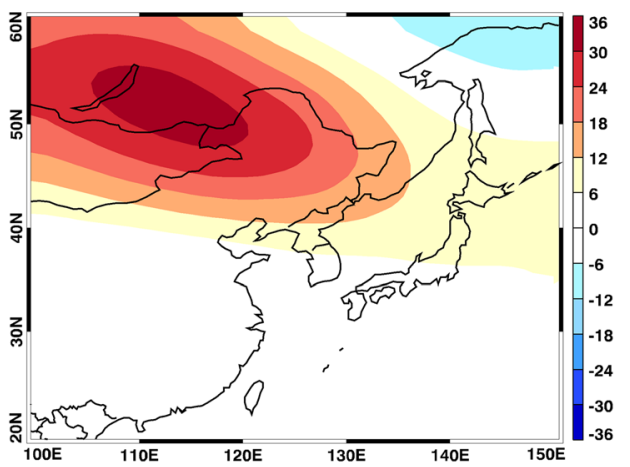

(e) $R=0.94$

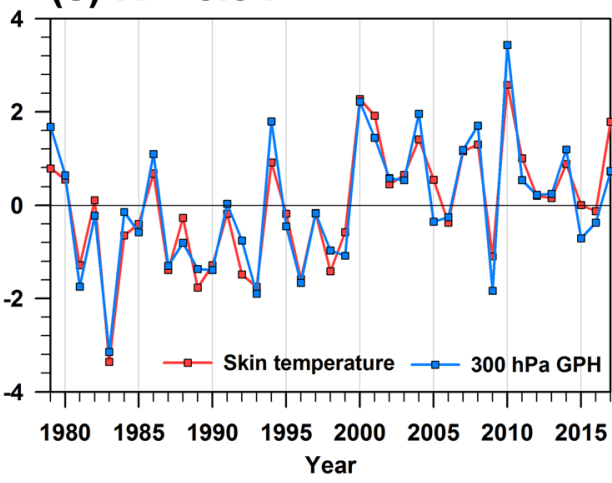

$2^{\text {nd }}$ mode $(18.1 \%)$

(b) Skin temperature

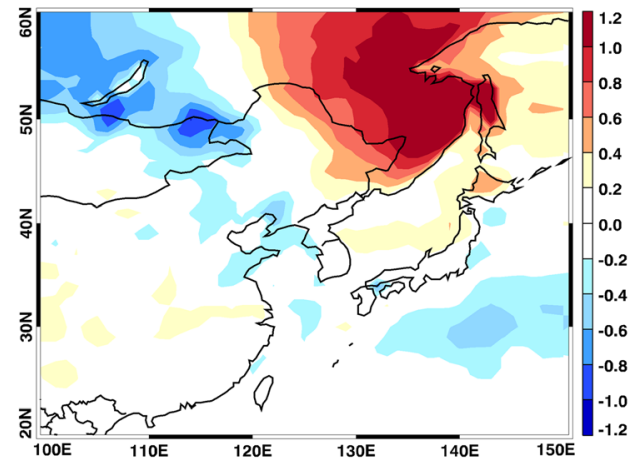

(d) $Z 300$

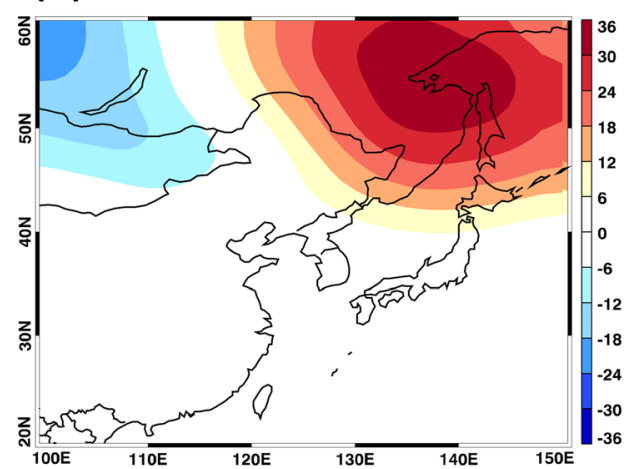

(f) $R=0.92$

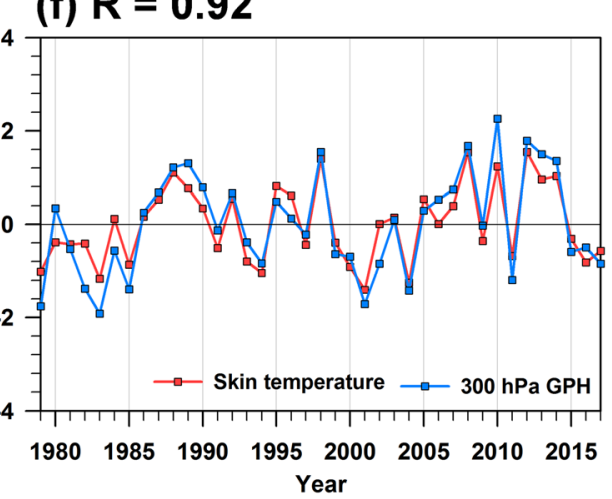

Russia (Figs. 8b and d). The surface cooling pattern over the northwestern Pacific is notable in the recent period (1998-2017), indicating the impact of the WNPSH is recently increased.

In order to identify when the temperature rise occurs abruptly, the Lepage test on the skin temperature is further performed. Here, the meridional average for the latitude band of $45-55^{\circ} \mathrm{N}$ is considered in the Lepage test because the two EOF modes with the temperate rises are divided into western and eastern parts (Figs. 7a-b). A sudden temperature change over the eastern part of Mongolia and Manchuria (115-130 $\mathrm{E})$ is clearly found in 1998-1999 (Fig. 9). Piao et al. (2017) also found the increased surface temperature and evapotranspiration, but decreased soil moisture and vegetation over the Mongolia to Northeast China regions after the late 1990s. Accordingly, the abrupt increase of surface temperature over the region may be related to the change of surface properties. This surface change can be influenced by not only natural variability but also human activities (e.g., over-farming, over-grazing, deforestation, and land-use change). Skin temperature over the far East of Russia $\left(130-135^{\circ} \mathrm{E}\right)$ also represents decadal change around the years of 2002-2005 (Fig. 9). In conclusion, the decadal changes in surface temperature during 1998-1999 and 2002-2005 appears to be associated with the first and second EOF modes, respectively. As a result of Lepage test to the PC time series of EOF modes, the first 
Fig. 7 Eigenvectors (top) and time series of principal component (PC; bottom) in first two leading EOF modes during June 1979-2017 (a) $1^{\text {st }}$ mode $(29.1 \%)$

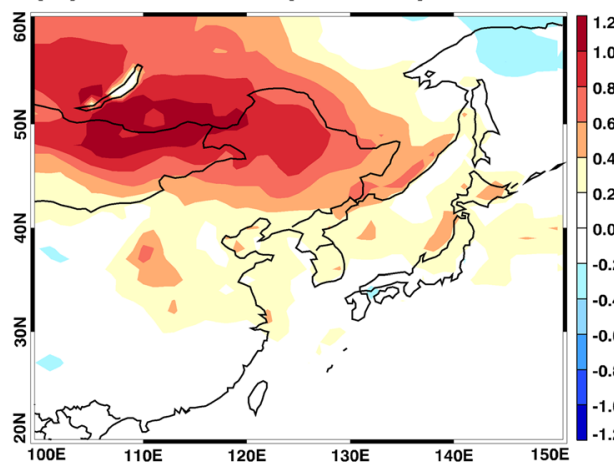

(c)

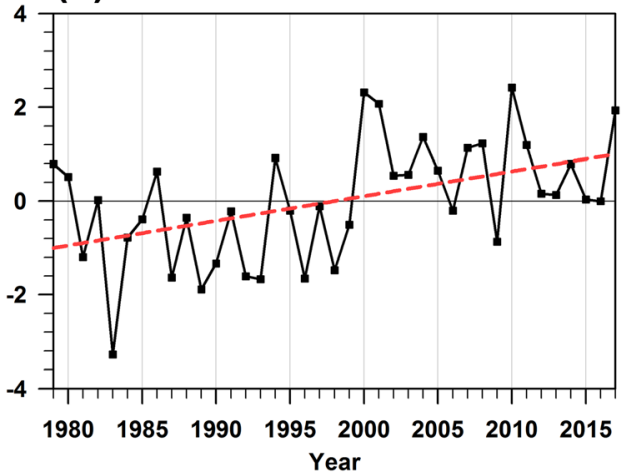

(b) $2^{\text {nd }}$ mode $(12.7 \%)$

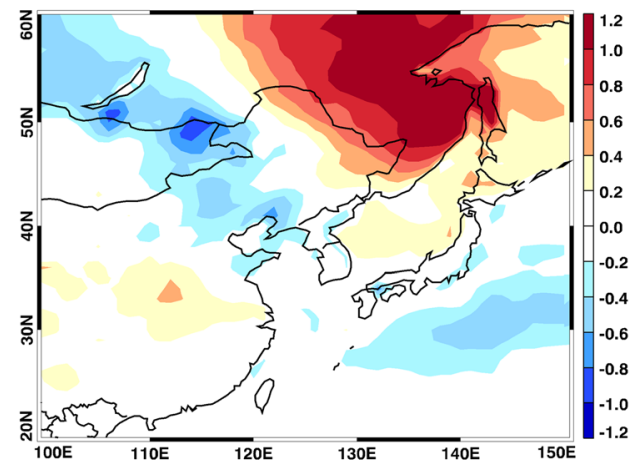

(d)

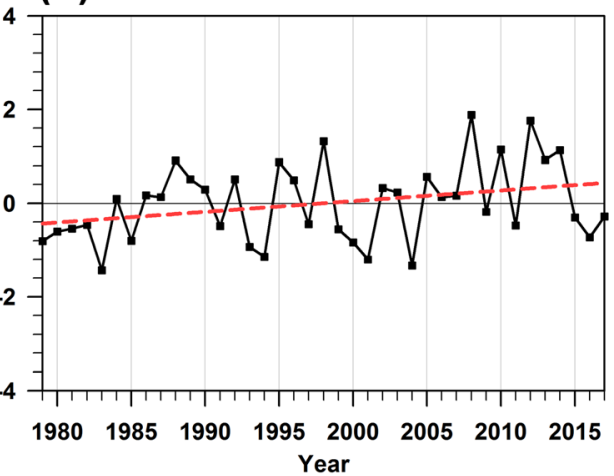

EOF mode clearly exhibits an abrupt change during the periods of 1998-1999 with 95\% confidence level. However, the PC time series of second EOF mode does not show significant change in the Lepage test, despite of the abrupt changes of surface temperature around 2005 over the far East of Russia in Fig. 9. This inconsistency is thought to be related with the regime shift in second EOF mode between previous (19791997) and recent (1998-2017) periods over the northwestern Pacific, as shown in Fig. 8. Thus, it can be interpreted that recent surface cooling over the northwestern Pacific (Fig. 8d) have affected to the variability of surface temperature over East Asia.

We can assume that the increasing trend of surface temperature in northeast Asia induces the change of EASM circulation, and then eventually leads to the decrease of June rainfall over the Korean peninsula, as well as the increased rainfall over the southeastern China and south of Japan. In order to support this hypothesis, this study analyses the regressed synoptic patterns against the time series of EOF modes. In the regression analysis, geopotential heights $(850,500$, and $300 \mathrm{hPa}$ levels), water vapor flux, moisture flux convergence, and rainfall are considered. Figures 10 and 11 show synoptic patterns regressed on the first and second EOF modes, respectively. The first EOF mode indicates an enhanced high pressure anomaly over the eastern part of Lake Baikal, Mongolia, and Manchuria regions (Figs. 10a-c). The low pressure anomaly over the Sea of Okhotsk is also prominent in the first EOF mode, indicating the weakening of Okhotsk high. The geopotential height patterns induce a decrease of moisture flux convergence on the eastern part of these regions along with an anticyclonic circulation shown in water vapor flux (Figs. 10de). Generally, the summer rainy season on the Korean peninsula begins with the northward propagation of the WNPSH, which can supply a large amount of water vapor in the southwest. However, the northeasterly or easterly water vapor flux patterns over the peninsula indicate that the supply of water vapor over the area is much suppressed. In other words, the impact of dry continental air mass on the Korean peninsula is enhanced. As a result, rainfall is also much reduced along the eastern periphery of anticyclone circulation, including the Manchuria and Korean peninsula regions (Fig. 10f).

The regression results on the second EOF mode represent the intensification of the high pressure anomaly over the far East of Russia from upper to lower troposphere (Figs. 11a-c). This pattern leads to a westward water vapor flux over the Korean peninsula, inducing the reduction of moisture flux convergence over that region (Figs. 11d-e). Furthermore, a cyclonic circulation in the lower troposphere is found over the southeastern China, East China Sea, and south of Japan islands around a long-extended latitude band of $30^{\circ} \mathrm{N}$ (Fig. 11a), although the similar pattern is not found in the middle and upper troposphere. This cyclonic circulation with 
Fig. 8 Same as Fig. 7, but for the previous (1978-1997) and recent (1998-2017) periods $1^{\text {st }}$ mode

(a) 1979-1997 (29.2\%)

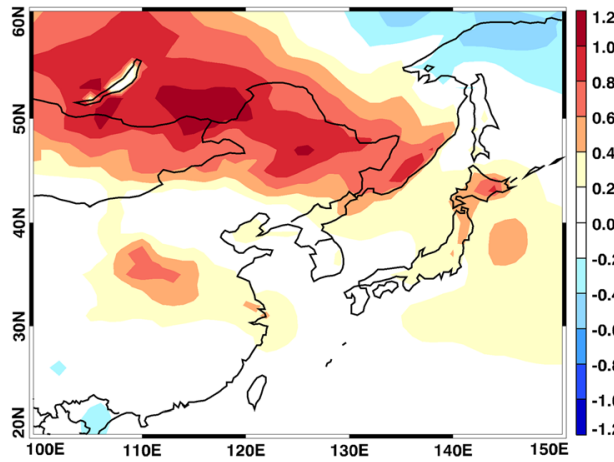

(c) 1998-2017 (26.9\%)

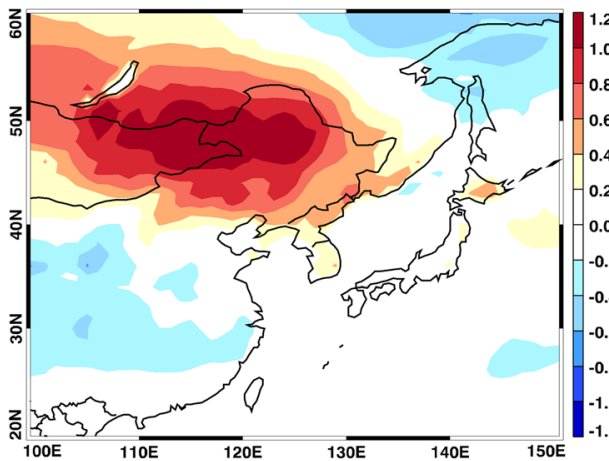

(e)

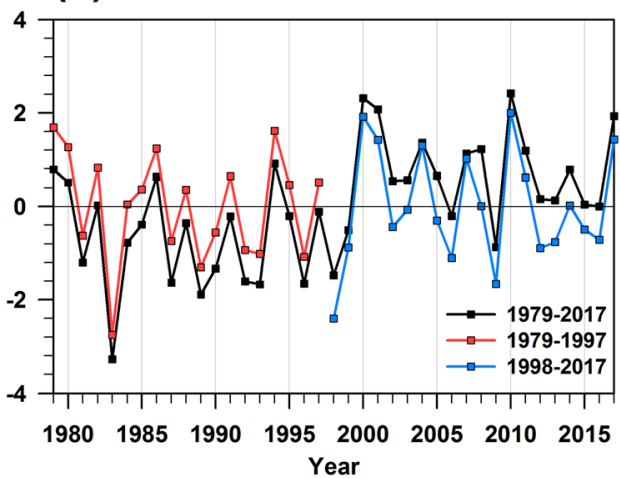

$2^{\text {nd }}$ mode

(b) 1979-1997 (13.9\%)

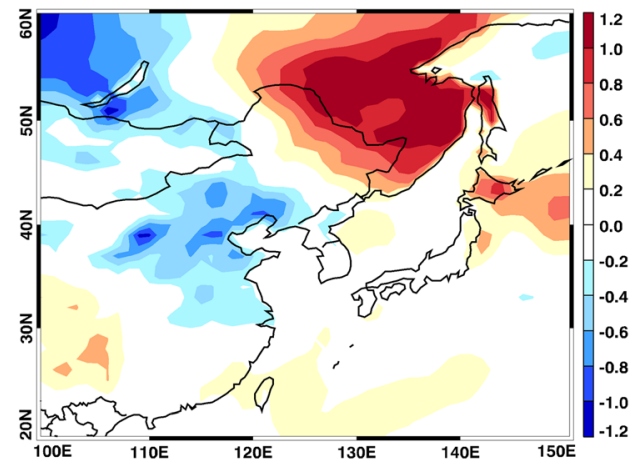

(d) 1998-2017 (17.2\%)

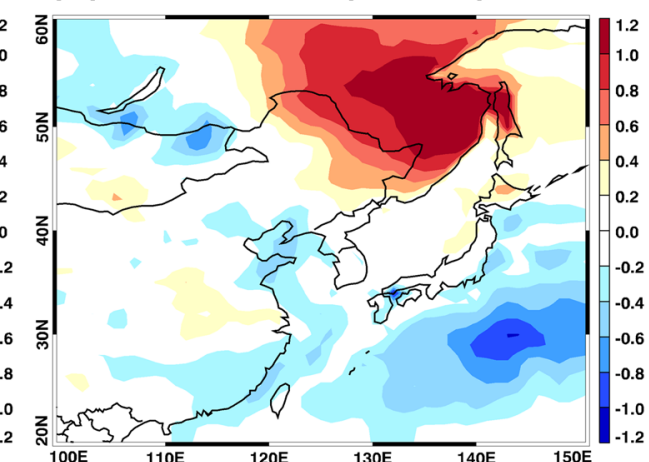

(f)

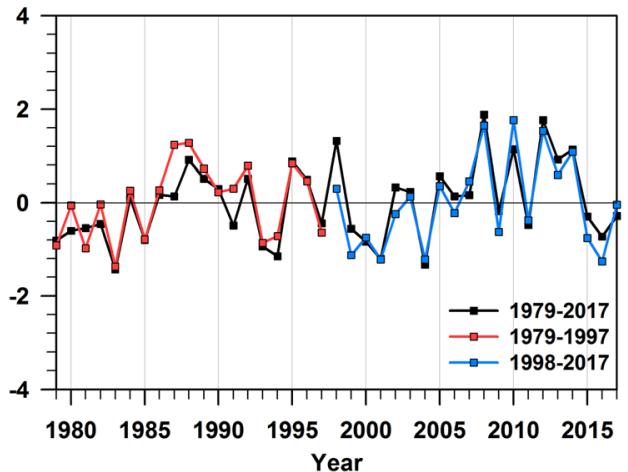

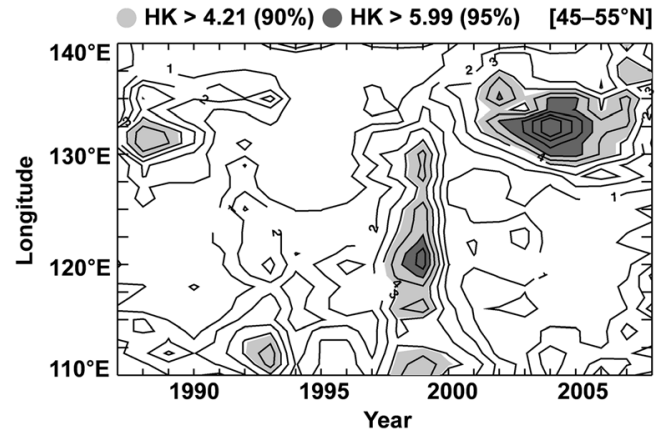

Fig. 9 Same as Fig. 2, but for meridional $\left(45-55^{\circ} \mathrm{N}\right)$ mean for skin temperature a long-extended band shape increases (decreases) moisture flux convergence and rainfall in the south (north) of band as shown in Figs. 11e-f. As a result, the regression results on the second EOF mode exhibit both the anticyclonic circulation over the far East of Russia and Sea of Okhotsk and the cyclonic circulation over the south of Japan islands. In summary, the combination of first and second EOF modes appear to influence droughts over the Korean peninsula (shown in Fig. 4f), through the strengthening of continental high pressure anomaly (anticyclonic circulation) over northeastern Asian regions (e.g., Lake Baikal, Mongolia, Manchuria, and far East of Russia) and weakening of water vapor transport over Korea. The enhanced cyclonic circulation over the south of 
(a) $\mathbf{Z 8 5 0}$

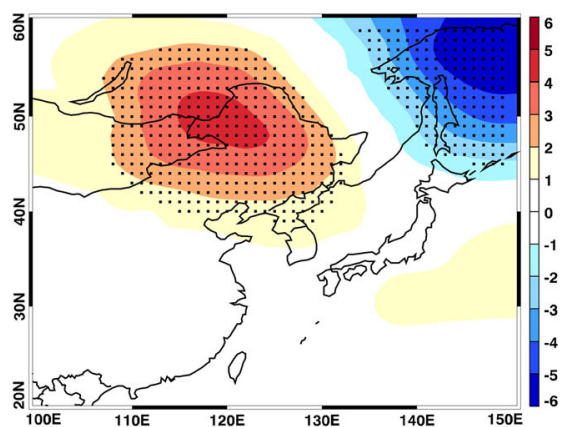

(d) Water Vapor Flux

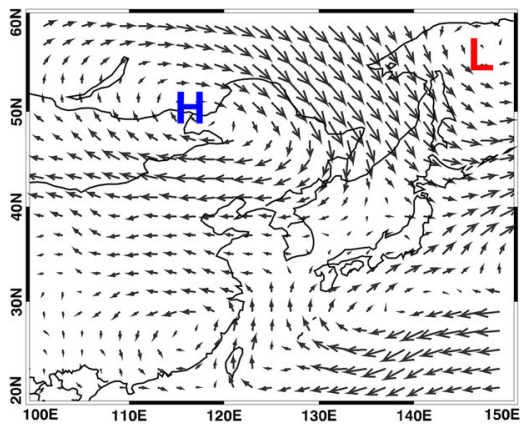

(b) Z500

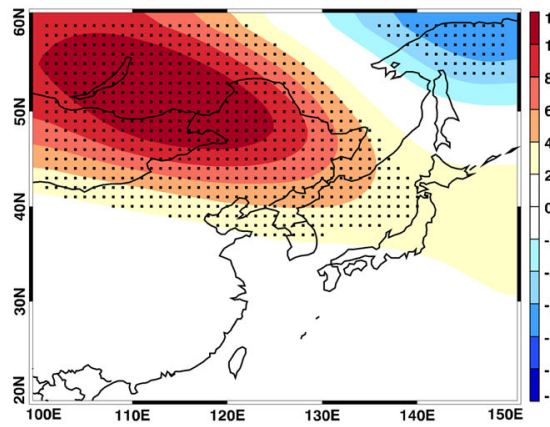

(e) Moisture Flux Convergence

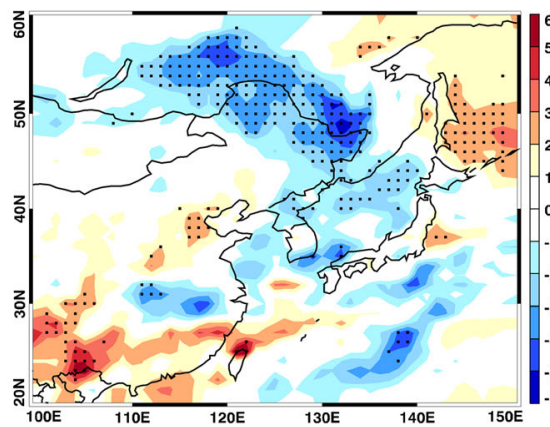

(c) Z300

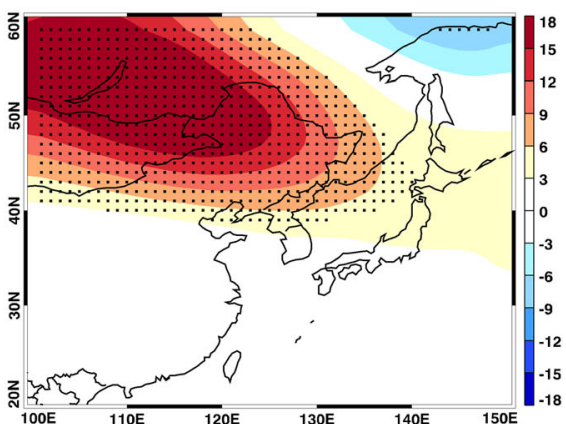

(f) Rainfall

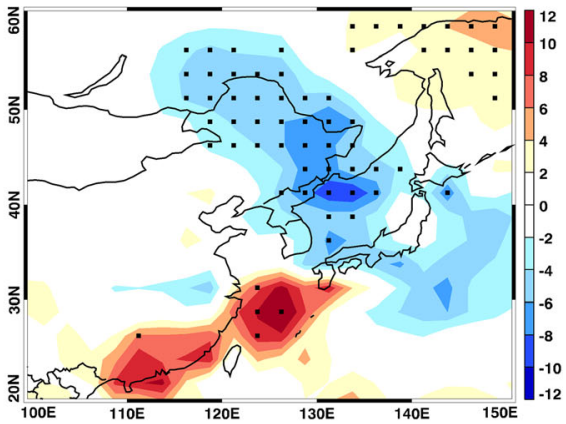

Fig. 10 Spatial patterns of regressed (a) $850-\mathrm{hPa}$, (b) 500-hPa, (c) 300hPa geopotential heights (Z850, Z500, Z300), (d) water vapor flux, (e) moisture flux convergence, and (f) rainfall against the PC time series in

Japan islands found in the second EOF mode is also thought to be related with recent droughts over the Korean peninsula by

\section{(a) Z850}

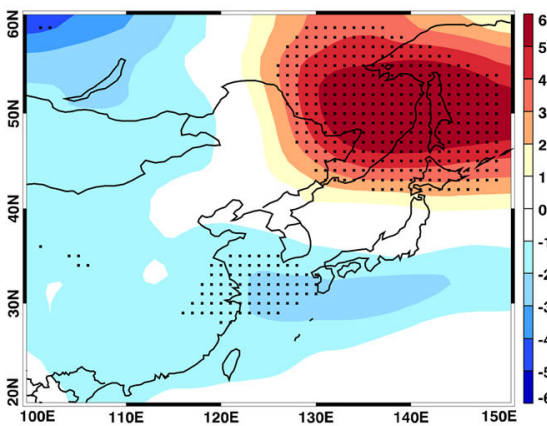

(d) Water Vapor Flux

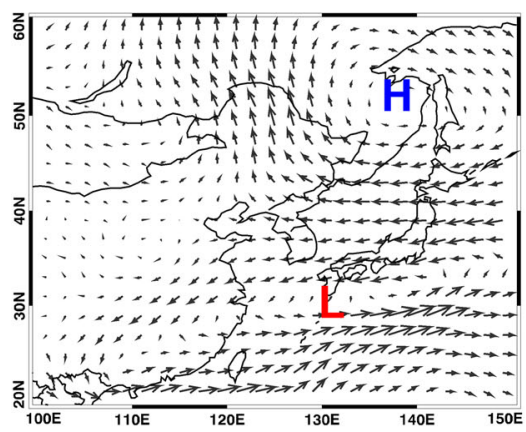

(b) Z500

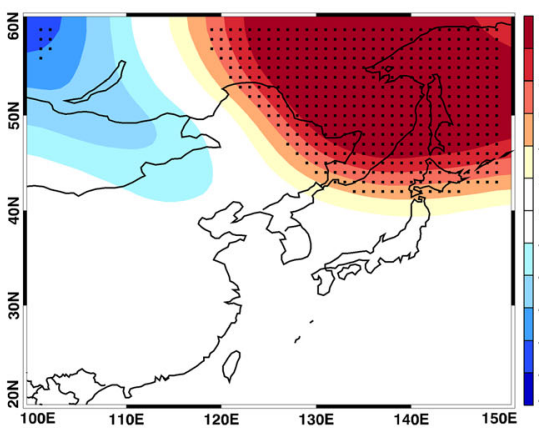

(e) Moisture Flux Convergence

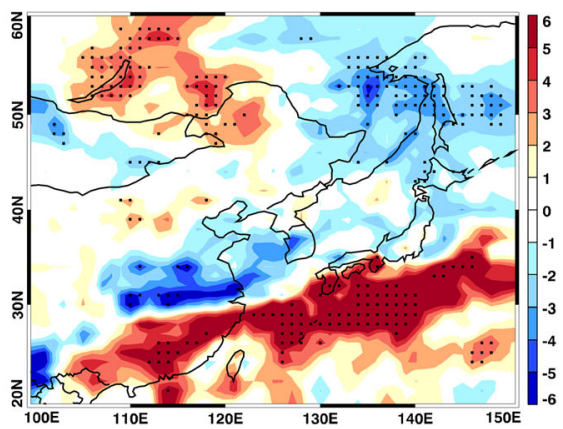

supporting the weakening of water vapor transport along with continental high pressure anomaly over the far East of Russia.

the first mode of skin temperature during June 1979-2017. Black squares within figures denote grid points which are significant at the $95 \%$ confidence level

(c) $Z 300$

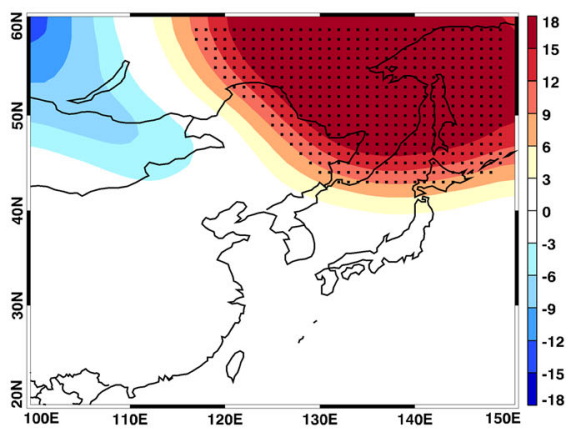

(f) Rainfall

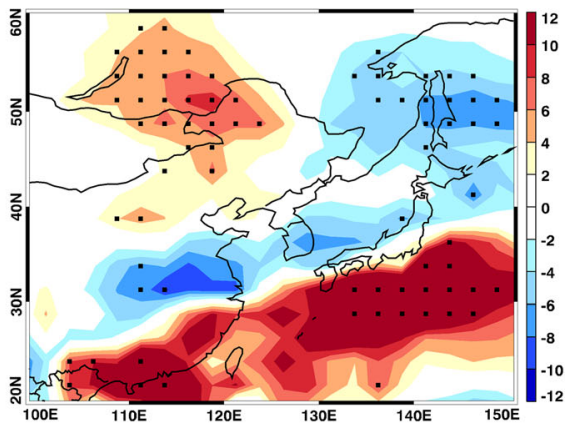

Fig. 11 Same as Fig. 10, except for the second mode of skin temperature 


\section{Conclusions}

The June rainfall over the Korean peninsula exhibited a gradual decreasing trend for the period of 1979-2017. In particular, the occurrence frequency of drought years after 1998 was twice as frequent compared with that before 1997, while there was no flood year during the recent 13 years (2005-2017). The decreasing trend of rainfall appeared in not only the Korean peninsula, but also in some parts of Japan. On the other hand, the rainfall over the southern China and East China Sea tended to increase for 39 years. This feature was thought to be the slower northward movement of EASM front. The Lepage test indicated that there was an abrupt change in the EASM rainfall over the latitude band of $31-36^{\circ} \mathrm{N}$ around the year of 1998 , as well as the $36-39^{\circ} \mathrm{N}$ region around 2004 . As a result of various statistical analyses, two important modes were noted, possibly resulting in decreasing rainfall over the Korean peninsula. The first EOF mode was associated with the increased surface temperature and high pressure anomalies over the eastern Lake Baikal, Mongolia, and Manchuria regions. This strengthened an anticyclonic circulation and induced change of water vapor transport pattern around the regions. It eventually contributed to the weakening of water vapor transport and decreased rainfall over the eastern Lake Baikal, eastern Manchuria, and Korean peninsula. The second EOF mode was characterized by the increased surface temperature and anticyclonic circulation over the far East of Russia as well as the strengthened cyclonic circulation in the lower troposphere over the East China Sea to the south of Japan islands. These circulation patterns reduced moisture flux convergence and rainfall along with a westward water vapor flux change in the north of the band (including the Korean peninsula), but enhanced moisture flux convergence and rainfall over the south of the band. The strengthening of continental high pressure anomaly over northeastern Asian regions found in both first and second EOF modes was thought to contribute droughts over Korea through the suppression for the northward propagation of EASM front in June. The enhanced anticyclonic circulation over the far East of Russia and cyclonic circulation over the East China Sea and south of Japan islands in the second EOF mode seems also influence recent droughts over the Korean peninsula because of induced easterly wind anomaly. In conclusion, the decreasing June rainfall over the Korean peninsula was interpreted as a part of the EASM circulation changes with local warming over northeastern Asian continent.

Acknowledgements The ASOS, GPCP, and ERA-Interim data used in this study were obtained from https://data.kma.go.kr, https://gpcp.ume. edu, and http://apps.ecmwf.int/datasets/data/interim-full-moda, respectively. This study was supported by the KMA Research and
Development Program under Grant No. KMI 2018-06910. HJS was also funded by the Korea Meteorological Administration R\&D Program "Enhancement of Convergence Technology of Analysis andForecast on Severe Weather" under Grant (1365003081).

Open Access This article is licensed under a Creative Commons Attribution 4.0 International License, which permits use, sharing, adaptation, distribution and reproduction in any medium or format, as long as you give appropriate credit to the original author(s) and the source, provide a link to the Creative Commons licence, and indicate if changes were made. The images or other third party material in this article are included in the article's Creative Commons licence, unless indicated otherwise in a credit line to the material. If material is not included in the article's Creative Commons licence and your intended use is not permitted by statutory regulation or exceeds the permitted use, you will need to obtain permission directly from the copyright holder. To view a copy of this licence, visit http://creativecommons.org/licenses/by/4.0/.

\section{References}

Adler, R.F., et al.: The Global Precipitation Climatology Project (GPCP) monthly analysis (new version 2.3) and a review of 2017 global precipitation. Atmos. 9(4), 138 (2018). https://doi.org/10.3390/ atmos 9040138

Dee, D.P., et al.: The ERA-Interim reanalysis: Configuration and performance of the data assimilation system. Q. J. R. Meteorol. Soc. 137, 553-597 (2011). https://doi.org/10.1002/qj.828

Ding, Y., Chan, J.C.L.: The east Asian summer monsoon: an overview. Meteorog. Atmos. Phys. 89, 117-142 (2005). https://doi.org/10. 1007/s00703-005-0125-Z

Ding, Y.H., Wang, Z.Y., Sun, Y.: Inter-decadal variation of the summer precipitation in East China and its association with decreasing Asian summer monsoon. Part I: Observed evidences. Int. J. Climatol. 228, 1139-1161 (2008). https://doi.org/10.1002/joc.1615

Ding, Y.H., Sun, Y., Wang, Z., Zhu, Y., Song, Y.: Inter-decadal variation of the summer precipitation in China and its association with decreasing Asian summer monsoon. Part II: possible causes. Int. J. Climatol. 29, 1926-1944 (2009). https://doi.org/10.1002/joc.1759

Ha, K.J., Lee, S.S.: On the interannual variability of the Bonin high associated with the east Asian summer monsoon rain. Clim. Dyn. 29, 67-83 (2007). https://doi.org/10.1007/s00382-006-0169-x

Ha, K.J., Heo, K.Y., Lee, S.S., Yun, K.S., Jhun, J.G.: Variability in the east Asian monsoon: a review. Meteorol. Appl. 19(2), 200-215 (2012). https://doi.org/10.1002/met.1320

Han, T., Chen, H., Wang, H.: Recent changes in summer precipitation in Northeast China and the background circulation. Int. J. Climatol. 35, 4210-4219 (2015). https://doi.org/10.1002/joc.4280

Han, T., Wang, H., Sun, J.: Strengthened relationship between eastern ENSO and summer precipitation over Northeast China. J. Clim. 30, 4497-4512 (2017). https://doi.org/10.1175/JCLI-D-16-0551.1

Han, T., He, S., Wang, H., Hao, X.: Enhanced influence of early-spring tropical Indian Ocean SST on the following early-summer precipitation over Northeast China. Clim. Dyn. 51, 4065-4076 (2018). https://doi.org/10.1007/s00382-017-3669-y

He, C., Zhou, T., Lin, A., Wu, B., Gu, D., Li, C., Zheng, B.: Enhanced or weakened western North Pacific subtropical high under global warming? Sci. Rep. 5, 16771 (2015). https://doi.org/10.1038/ srep16771

Kwon, M.H., Jhun, J.G., Ha, K.J.: Decadal change in east Asian summer monsoon circulation in the mid-1990s. Geophys. Res. Lett. 34, L21706 (2007). https://doi.org/10.1029/2007GL031977 
Lee, J.Y., et al.: The long-term variability of Changma in the east Asian summer monsoon system: a review and revisit. Asia-Pac. J. Atmos. Sci. 53(2), 257-272 (2017). https://doi.org/10.1007/s13143-0170032-5

Li, H., Chen, H., Wang, H.: Can Barents Sea ice decline in spring enhance summer hot drought events over northeastern China? J. Clim. 31, 4705-4725 (2018). https://doi.org/10.1175/JCLI-D-17-0429.1

Lin, Z., Wang, B.: Northern east Asian low and its impact on the interannual variation of east Asian summer rainfall. Clim. Dyn. 46, 83-97 (2016). https://doi.org/10.1007/s00382-015-2570-9

Piao, J.L., Chen, W., Wei, K., Liu, Y., Graf, H.F., Ahn, J.B., Pogoreltsev, A.: An abrupt rainfall decrease over the Asian inland plateau region around 1999 and the possible underlying mechanism. Adv. Atmos. Sci. 34, 456-468 (2017). https://doi.org/10.1007/s00376-016-61365

Sampe, T., Xie, S.P.: Large-scale dynamics of the Meiyu-Baiu Rainband: environmental forcing by the westerly jet. J. Clim. 23, 113-134 (2010). https://doi.org/10.1175/2009JCLI3128.1

Sohn, B.J., Ryu, G.-H., Song, H.-J., Oh, M.-L.: Characteristic features of warm-type rain producing heavy rainfall over the Korean peninsula inferred from TRMM measurements. Mon. Weather Rev. 141, 3873-3888 (2013). https://doi.org/10.1175/MWR-D-13-00075.1

Song, H.-J., Sohn, B.J.: Two heavy rainfall types over the Korean peninsula in the humid east Asian summer environment: a satellite observation study. Mon. Weather Rev. 143, 363-382 (2015). https://doi. org/10.1175/MWR-D-14-00184.1

Song, H.-J., Sohn, B.J.: Polarizing rain types linked to June drought in the Korean peninsula over last 20 years. Int. J. Climatol. (2019). https:// doi.org/10.1002/joc.6325

Sun, L., Shen, B., Sui, B.: The influences of east Asian monsoon on summer precipitation in Northeast China. Clim. Dyn. 48, 16471659 (2017). https://doi.org/10.1007/s00382-016-3165-9

Tomita, T., Yamaura, T., Hashimoto, T.: Interannual variability of the baiu season near Japan evaluated from the equivalent potential temperature. J. Meteor. Soc. Japan. 89, 517-537 (2011). https://doi.org/10. 2151/jmsj.2011-507

Ueda, H., Kamae, Y., Hayasaki, M., Kitoh, A., Watanabe, S., Miki, Y., Kumai, A.: Combined effects of recent Pacific cooling and Indian Ocean warming on the Asian monsoon. Nat. Commun. 6, 8854 (2015). https://doi.org/10.1038/ncomms 9854
Wang, Y.: Effects of blocking anticyclones in Eurasia in the rainy season (Meiyu/Baiu season). J. Meteor. Soc. Japan. 70, 929-951 (1992). https://doi.org/10.2151/jmsj1965.70.5 929

Wang, H., He, S.: The North China/northeastern Asia severe summer drought in 2014. J. Clim. 28, 6667-6681 (2015). https://doi.org/ 10.1175/JCLI-D-15-0202.1

Wang, B., LinHo: Rainy season of the Asian-Pacific summer monsoon. J. Clim. 15, 386-398 (2002). https://doi.org/10.1175/15200442(2002)015<0386:RSOTAP>2.0.CO;2

Wang, Z., Ding, Y., Lu, M., Zhou, B., Yang, S., Jiang, X., Ke, Z.: Interseasonal variability and predictability of the subtropical Asian summer rain band. Int. J. Climatol. 37, 4119-4130 (2017). https:// doi.org/10.1002/joc.5033

Xiang, B., Wang, B.: Mechanisms for the advanced Asian summer monsoon onset since the mid-to-late 1990s. J. Clim. 26, 1993-2009 (2013). https://doi.org/10.1175/JCLI-D-12-00445.1

$\mathrm{Xu}, \mathrm{Z}$., Fan, K., Wang, H.J.: Decadal variation of summer precipitation over China and associated atmospheric circulation after the late 1990s. J. Clim. 28, 4086-5106 (2015). https://doi.org/10.1175/ JCLI-D-14-00464.1

Yim, S.Y., Wang, B., Kwon, M.H.: Interdecadal change of the controlling mechanisms for east Asian early summer rainfall variation around the mid-1990s. Clim. Dyn. 42, 1325-1333 (2014). https://doi.org/ 10.1007/s00382-013-1760-6

Yonetani, T.: Discontinuous changes of precipitation in Japan after 1900 detected by the Lepage test. J. Meteor. Soc. Japan. 70, 95-104 (1992). https://doi.org/10.2151/jmsj1965.70.1_95

Zhang, L., Zhou, T.: Drought over East Asia: a review. J. Clim. 28, 33753399 (2015). https://doi.org/10.1175/JCLI-D-14-00259.1

Zhang, H., Wen, Z., Wu, R., Li, Z., Chen, R.: An inter-decadal increase in summer sea level pressure over the Mongolian region around the early 1990s. Clim. Dym. 52, 1935-1948 (2019). https://doi.org/10. 1007/s00382-018-4228-x

Zhu, C.W., Wang, B., Qian, W., Zhang, B.: Recent weakening of northern east Asian summer monsoon: a possible response to global warming. Geophys. Res. Lett. 39, 278-283 (2012). https://doi.org/ 10.1029/2012GL051155

Publisher's Note Springer Nature remains neutral with regard to jurisdictional claims in published maps and institutional affiliations. 